\title{
Water Quality Analysis in Acharya Nagarjuna University Region, Guntur, Andhra Pradesh, India
}

\author{
Sudhakar Gummad ${ }^{1}$, Swarnalatha $\mathrm{G}^{2}$, P.Brahmaji Rao ${ }^{3}$, V. Venkataratnamma ${ }^{4}$ \\ ${ }^{1 \& 2}$ Research Scholar, Dept of Environmental Sciences, Acharya Nagarjuna University, Guntur \\ ${ }^{2}$ Assistant Professor, Dept of Environmental Sciences, Acharya Nagarjuna University, Guntur \\ ${ }^{3}$ Assistant Professor, Dept of Zoology, Acharya Nagarjuna University, Guntur
}

\begin{abstract}
Groundwater systems are dynamic and that is not available and not suitable for drinking purpose in all regions of the world, so it is very precious, the ground water samples are collected from different locations in Acharya Nagarjuna University, Nagarjuna Nagar, Guntur, and Andhra Pradesh, India. The water samples were analyzed to determine the concentration of physico chemical parameters to assess groundwater quality, the samples were collected and analyzed The analysis of different parameters such as $\mathrm{pH}$, Electrical conductivity, TDS, Sulphate, Sodium, Magnesium, Nitrate, Chloride, Fluorides, Total Alkalinity, Total hardness, and Iron were carried out as per standard methods in the laboratory. Results showed that Electrical conductivity, total dissolved solids (TDS) sodium $\left(\mathrm{Na}^{+}\right)$, magnesium $\left(\mathrm{Mg}^{2+}\right)$, Flouried $\left(\mathrm{F}^{-}\right)$concentrations are very high and chloride $\left(\mathrm{Cl}^{-}\right)$, Total hardness are slightly damage the groundwater. The analysis reveals that the groundwater needs treatment before consumption for drinking and domestic purpose.
\end{abstract}

Keywords: Consumption, Ground water, Physico- chemical, Standards,

\section{Introduction}

Water is the most important natural resource, which forms the core of ecological system. Recently there has been overall development in various fields such as agriculture, industry and urbanization in India. This has lead to increase in the demand of water supply which is met mostly from exploitation of groundwater resources.

Ground water quality has become an important water resources issue due to rapid increase of population, rapid industrialization, unplanned urbanization, flow of pollution from upland to lowland, and too much use of fertilizers, pesticides in agriculture (Joarder et al, 2008). Groundwater quality depends on the quality of recharged water, atmospheric precipitation, inland surface water, and on sub-surface geochemical processes. (Vasanthavigar et al 2010).

The drinking water quality depends on many physicochemical parameters and their concentrations, which are derived from laboratory tests on water samples.(Mohammad et al, 2013), Hydro chemical study is a useful tool to identify the suitability of the groundwater. The physical parameters taken into consideration in the present study are color, odor, turbidity and temperature. The chemical parameters taken into consideration are hydrogen ion concentration $(\mathrm{pH})$, specific conductance (EC), total dissolved solids (TDS), total hardness (TH) and all major cations and anions. Various workers in our country had carried out extensive studies on water quality have studied groundwater (Selvam et al, 2013)

The differences in the water quality can be attributed to the problems associated during the conveyance and distributions. Groundwater quality depends on the type of polluting sources in the surroundings and hence changes from location to location.( Ramakrishna-2014),

The physico-chemical parameters of groundwater such as $\mathrm{pH}$, Chlorides, Sodium, Calcium, Magnesium, Total Dissolved Solids (TDS), Electrical Conductivity (EC), Fluoride etc subsequently varies from location to location (Ramakrishna 2011)

Hence, evaluation of groundwater quantity and quality is important for the development of further civilization and to establish database for planning future water resources development strategies (Vasanthavigar et al 2010)

\subsection{Study area}

\section{Materials And Methods}

Acharya Nagarjuna University is one of the lush green region and situated between the cities of Vijayawada and Guntur in Andhra Pradesh, at a distance of $12 \mathrm{~km}$ from Guntur and $19 \mathrm{~km}$ from Vijayawada, Krishna district, Andhra Pradesh, and on Calcutta and Chennai National high way (NH-5), lies within the latitude $-16^{\circ} 48^{\prime}$ North and the longitude- $80^{\circ} .17$ ' East. Its campus is spread over an area of 293 acres; its affiliation jurisdiction extends over two districts of Guntur and Prakasam in Andhra Pradesh, India (Fig 1). 
The University has successfully overcome most of the initial problems and is moving forward with determination, enthusiasm and hope. At present offers post-graduation in 45 courses and 5 Graduate courses in the campus and having 13 (boys and girls) hostels and 48 departments along with Engineering and Pharmacy colleges for graduate and post graduation courses. The students, research scholars, teaching and non teaching staff depend on surface and ground water for drinking and domestic purpose and also use the water for laboratory purpose in various departments. So drinking water is very important in this region. Seven sampling stations were selected for the collection of ground water for this study in the March, 2014.

Fig 1: Study area Acharya Nagarjuna University

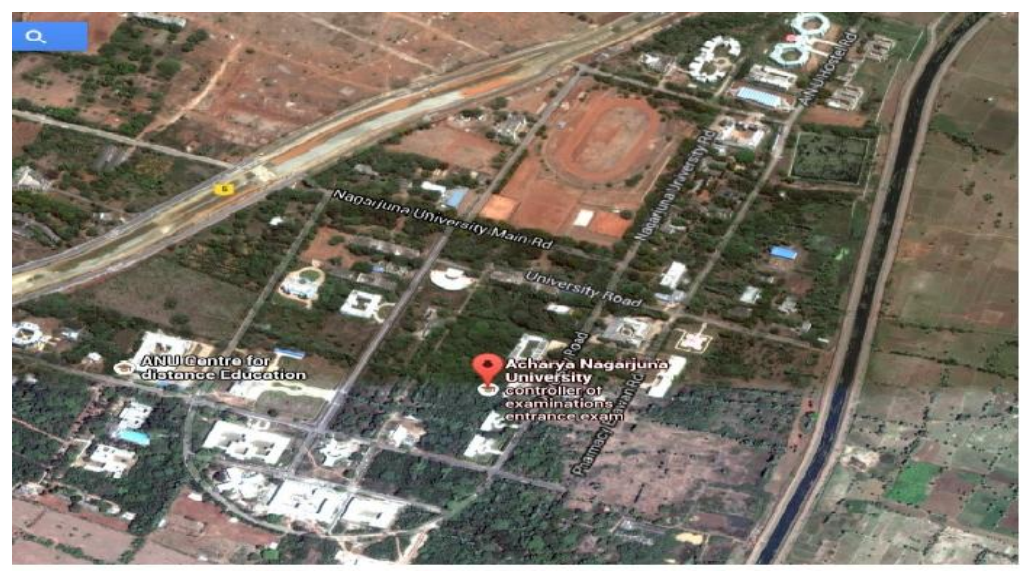

\subsection{Sample Collection and Method of Analysis}

The drinking water quality depends on many physico-chemical parameters and their concentrations, which are derived from laboratory tests of water samples. Water samples were collected in clean polyethylene bottles from different sources by using standard techniques (WHO, 2004, APHA 1995)

Twelve parameters for the estimation of drinking water characteristics are adopted such as: $\mathrm{pH}$, electrical conductivity (EC), total dissolved solids (TDS), total hardness (TH) Magnesium $\left(\mathrm{Mg}^{2+}\right)$, Sulphate $\left(\mathrm{SO}_{4}{ }^{2-}\right)$, Nitrates $\left(\mathrm{NO}_{3}^{-}\right)$, Sodium $\left(\mathrm{Na}^{+}\right)$, Fluoride $\left(\mathrm{F}^{-}\right)$, Chlorides $\left(\mathrm{Cl}^{-}\right)$, Iron $(\mathrm{Fe})$, and Total alkalinity by using standard the techniques (WHO 1996, APHA, 1998). The temperature of the water Samples is in the range 25$30^{\circ} \mathrm{C}$. (Mohammad et al, 2013)

The suitability of groundwater for drinking and other purposes may be assessed by comparing physical and chemical parameters of the study area with the guidelines recommended by World Health Organization (WHO, 2004). BIS and USPH. The perusal of the results revealed that the water is safe for drinking and domestic purposes in selected sampling regions.

The samples were analyzed in the laboratory methods that are $\mathrm{pH}$, Electrical conductivity (EC), and total dissolved solids (TDS) were measured by Water Quality Analyzer. Magnesium (Mg) was determined titrimetrically using standard EDTA. Chloride $\left(\mathrm{Cl}^{-}\right)$was determined by standard $\mathrm{AgNO}_{3}$ titration, Sodium $\left(\mathrm{Na}^{+}\right)$ by flame photometry. Sulfate $\left(\mathrm{SO}_{4}{ }^{2-}\right)$, was determined by spectrophotometer. Nitrate $\left(\mathrm{NO}_{3}{ }^{-}\right)$and fluoride $\left(\mathrm{F}^{-}\right)$ were analyzed by using ion-sensitive electrode.

\section{Results \& Discursion}

The results of the hydrochemical analysis of the groundwater samples taken from the study area are shown in Table 1.The $\mathrm{pH}$ was slightly alkaline in all stations. It was within the permissible limit as per BIS standards (Ramakrishnaiah et al, 2009). The Electrical conductivity range from $480 \mathrm{mg} / \mathrm{l}$ to $4550 \mathrm{mg} / \mathrm{l}$, when compared with standards EC level is very high in all samples (Table 1 \& 2), Comparison of hydrochemical data with drinking water standards (WHO 1984), The TDS is one of the important parameter for the use of drinking water, the water with high TDS value indicates that water is highly mineralized, (Sudhakar \& Swarna Latha, 2013, Kumar .M \& Kumar R, 2012) minimum range is $307 \mathrm{mg} / 1$ in Sample5 remaining all samples are exceeding the standard levels (WHO/BIS/USPH-500 mg/l).

The sodium concentration is high in all samples the range from 98 to $260 \mathrm{mg} / \mathrm{l}$, magnesium range in water samples 139 to $280 \mathrm{mg} / \mathrm{l}$ but the standard level is $30 \mathrm{mg} / \mathrm{l}$ (table 2). Chloride level is significant range except sample number 3 that the maximum level is $900 \mathrm{mg} / \mathrm{l}$, high chloride concentration indicates organic pollutants in the water (Tripathi et al, 1989). According to WHO and BIS standards the limit of fluoride is 1.0 to $1.5 \mathrm{mg} / \mathrm{L}$ (Table 2). Table-1 showed that the concentration of F-lies between 1 to $3.3 \mathrm{mg} / \mathrm{L}$. If the $\mathrm{F}$ concentration is between 0.9 to $1.2 \mathrm{mg} / \mathrm{L}$ then dental fluorosis is started and F - exceeds the level of $3 \mathrm{mg} / \mathrm{L}$ then skeletal fluorosis is started in living beings. (Kalwale \& Savale 2012). Alkalinity is the water is measure of its 
neutralize acids this is due to salt of weak acids of strong base, the carbonates and bicarbonates represents the measure of alkalinity (Sudhakar \& Swarna Latha, 2013), the values lies between 244-348 mg/l it indicated in Table 1.the total hardness range between $124-1124 \mathrm{mg} / 1$, and the guidelines value is $300 \mathrm{mg} / \mathrm{l}$, the table 1 showed that sample 2 and sample 3 exceeding the standard level. Permanent hardness is caused by the presence of calcium, magnesium chlorides, and sulfates and can be cured only with ion exchange processes. (Vasanthavigar et al 2010). The Iron concentration is slightly high level in sample3.

The important physico-chemical characteristics of analyzed water samples viz., Min, Max, Mean, And Standard Deviation (SD), have been presented in Table 2 and the values are compared with standard parameters in Table 3.

The correlation study is useful to find a predictable relationship which can be exploited in practices; correlation is a broad class of statistical relationship between two or more variables. It is used for the measurement of the strength and statistical significance of the relation between two are more water quality (Mehta, K.V., 2010), in the correlation of the water samples

\section{Figures And Tables}

Table1: Physicochemical parameters of drinking water at studied region

\begin{tabular}{|c|c|c|c|c|c|c|c|c|c|c|c|c|}
\hline Samples & $\mathrm{pH}$ & $\mathrm{EC}$ & $\mathrm{TDS}$ & $\mathrm{SO}_{4}$ & $\mathrm{Na}$ & $\mathrm{Mg}$ & $\mathrm{Cl}$ & $\mathrm{NO}_{3}$ & $\mathrm{~F}$ & $\mathrm{TA}$ & $\mathrm{TH}$ & $\mathrm{Fe}$ \\
\hline $\mathrm{S} 1$ & 7.98 & 810 & 518 & 32 & 260 & 189 & 90 & 20 & 1.7 & 284 & 200 & 0 \\
\hline S2 & 7.88 & 1540 & 986 & 56 & 124 & 280 & 180 & 12 & 3.3 & 264 & 360 & 0 \\
\hline S3 & 8.05 & 4550 & 2912 & 180 & 101 & 139 & 900 & 15 & 3.2 & 320 & 1124 & 1 \\
\hline S4 & 7.92 & 1125 & 720 & 44 & 120 & 170 & 120 & 0 & 2.1 & 300 & 280 & 0 \\
\hline S5 & 8.25 & 480 & 307 & 16 & 105 & 153 & 80 & 24 & 1 & 348 & 124 & 0 \\
\hline S6 & 7.96 & 890 & 570 & 28 & 98 & 200 & 120 & 10 & 1.6 & 300 & 216 & 0 \\
\hline S7 & 7.64 & 1180 & 755 & 42 & 218 & 142 & 150 & 15 & 2.6 & 244 & 296 & 0 \\
\hline
\end{tabular}

Table2: Drinking Water standards recommending Agencies and unit weights. (All values except $\mathrm{pH}$ and Electrical Conductivity are in $\mathrm{mg} / \mathrm{L}$ )

\begin{tabular}{|c|c|c|c|}
\hline S/No & Parameters & Standards & Recommended Agency \\
\hline 1 & $\mathrm{pH}$ & $6.5-8.5$ & WHO/BIS/USPH \\
\hline 2 & EC & 300 & WHO/USPH \\
\hline 3 & TDS & 500 & WHO/BIS/USPH \\
\hline 4 & Sulphates & 200 & WHO/BIS/USPH \\
\hline 5 & Na & $50-60$ & WHO \\
\hline 6 & Magnesium & 30 & WHO/BIS/USPH \\
\hline 7 & Nitrates & 45 & WHO/BIS \\
\hline 8 & Chlorides & 250 & WHO/BIS/USPH \\
\hline 9 & Flouried & $1-1.5 \mathrm{ppm}$ & WHO/BIS \\
\hline 10 & Total alkalanity & -- & --- \\
\hline 11 & Total Hardness & 300 & WHO/BIS/USPH \\
\hline 12 & Iron & 0.1 & WHO/BIS \\
\hline
\end{tabular}

Table 3: Descriptive statistics of the groundwater samples in study region

\begin{tabular}{|c|c|c|c|c|c|c|c|c|c|}
\hline Parameters & Units & Min & Max & Mean & SD & SE & Variance & Skewness & kurtosis \\
\hline $\mathrm{pH}$ & - & 7.64 & 8.25 & 7.954 & 0.183 & 0.069 & 0.0337 & -0.109 & -0.808 \\
\hline $\mathrm{EC}$ & $\mu \mathrm{S} / \mathrm{cm}$ & 480 & 4550 & 1510.71 & 1380.51 & 521.785 & 1.905 & 1.428 & 0.417 \\
\hline $\mathrm{TDS}$ & $\mathrm{mg} / \mathrm{l}$ & 307 & 2912 & 966.85 & 883.56 & 333.957 & 78069 & 1.427 & 0.416 \\
\hline $\mathrm{SO}_{4}$ & $\mathrm{mg} / \mathrm{l}$ & 16 & 180 & 56.85 & 55.78 & 21.084 & 3111.8 & 1.4437 & 0.45 \\
\hline $\mathrm{Na}$ & $\mathrm{mg} / \mathrm{l}$ & 98 & 260 & 146.57 & 64.99 & 24.566 & 4224.6 & 0.786 & -1.357 \\
\hline $\mathrm{Mg}$ & $\mathrm{mg} / \mathrm{l}$ & 139 & 280 & 181.85 & 49.008 & 18.523 & 2401.8 & 0.951 & -0.536 \\
\hline $\mathrm{NO}_{3}$ & $\mathrm{mg} / \mathrm{l}$ & 0 & 24 & 13.71 & 7.67 & 2.9 & 58.904 & -0.409 & -1.01 \\
\hline $\mathrm{Cl}$ & $\mathrm{mg} / \mathrm{l}$ & 80 & 900 & 234.28 & 295.51 & 111.694 & 87328 & 1.575 & 0.705 \\
\hline $\mathrm{F}$ & $\mathrm{mg} / \mathrm{l}$ & 1 & 3.3 & 2.21 & 0.85 & 0.324 & 0.738 & 0.03 & -1.756 \\
\hline $\mathrm{TA}$ & $\mathrm{mg} / \mathrm{l}$ & 244 & 348 & 294.28 & 34.55 & 13.059 & 1193.9 & 0.056 & -1.395 \\
\hline $\mathrm{TH}$ & $\mathrm{mg} / \mathrm{l}$ & 124 & 1124 & 371.42 & 340.41 & 128.66 & 1158 & 1.452 & 0.468 \\
\hline $\mathrm{Fe}$ & $\mathrm{mg} / \mathrm{l}$ & 0 & 1 & 0.14 & 0.37 & 0.142 & 0.142 & 1.619 & 0.795 \\
\hline
\end{tabular}


Table 4: correlation coefficient in Ground water

\begin{tabular}{|c|c|c|c|c|c|c|c|c|c|c|c|c|}
\hline & $\mathrm{pH}$ & $\mathrm{EC}$ & TDS & $\mathrm{SO}_{4}$ & $\mathrm{Na}$ & $\mathrm{Mg}$ & $\mathrm{Cl}$ & $\mathrm{NO}_{3}$ & $\mathrm{~F}$ & TA & $\mathrm{TH}$ & $\mathrm{Fe}$ \\
\hline$\overline{\mathrm{pH}}$ & 1 & & & & & & & & & & & \\
\hline $\mathrm{EC}$ & 0.052 & 1 & & & & & & & & & & \\
\hline TDS & 0.052 & 1 & 1 & & & & & & & & & \\
\hline $\mathrm{SO}_{4}$ & 0.066 & 0.998 & 0.99 & 1 & & & & & & & & \\
\hline $\mathrm{Na}$ & -0.472 & -0.297 & -0.295 & -0.277 & 1 & & & & & & & \\
\hline $\mathrm{Mg}$ & -0.124 & -0.236 & -0.236 & -0.254 & -0.087 & 1 & & & & & & \\
\hline $\mathrm{Cl}$ & 0.147 & 0.99 & 0.99 & 0.990 & -0.316 & -0.319 & 1 & & & & & \\
\hline $\mathrm{NO}_{3}$ & 0.413 & -0.062 & -0.062 & -0.058 & 0.301 & -0.191 & 0.024 & 1 & & & & \\
\hline $\mathrm{F}$ & -0.505 & 0.693 & 0.693 & 0.682 & -0.05 & 0.279 & 0.597 & -0.302 & 1 & & & \\
\hline TA & 0.943 & 0.139 & 0.139 & 0.152 & -0.586 & -0.36 & 0.243 & 0.256 & -0.511 & 1 & & \\
\hline TH & 0.056 & 0.999 & 0.999 & 0.999 & -0.29 & -0.261 & 0.992 & -0.057 & 0.68 & 0.149 & 1 & \\
\hline $\mathrm{Fe}$ & 0.229 & 0.97 & 0.97 & 0.9734 & -0.309 & -0.385 & 0.993 & 0.073 & 0.505 & 0.328 & 0.974 & 1 \\
\hline
\end{tabular}

Strong: 13, moderate: 6 , Weak: 17, Negative: 26

\section{Conclusion}

The quality of groundwater sample collected from seven different locations of Acharya Nagarjuna University, Guntur, On the basis of these analytical findings, the following conclusions can be drawn. The $\mathrm{pH}$ of the entire water sample is well within permissible limits. The TDS and Total hardness values of all the water samples are not within permissible limits. Total alkalinity values for all the samples are within permissible limit. Sodium and Magnesium content for all samples has high value above permissible limits. Chlorides content in sample-3 high range but remaining all samples are permissible limits. Sulphate and Nitrate content for all samples is within permissible limits. The fluoride content is very high in all samples except Sample-5, it is effect to the bones and teeth, The general observation is that the samples of water from Acharya Nagarjuna University is required to treatment before consumption. In the university the water treatment plant is treat the water but the parameters are not maintained within the permissible range. Hence, rapid and reliable monitoring measures are essential for keeping a close watch on water quality and health environment. In the correlation regression study, we can conclude that all the parameters are more or less correlated with each other. The linear correlation is very useful to get fairly accurate idea of quality of the groundwater by determining a few parameters experimentally.

\section{Reference}

[1]. Joarder M A. M, Raihan F, Alam J B, and Hasanuzzaman S, (2008), Study on A Ground water quality, Int. J. Environ. Res.2(3), 291

[2]. M. Vasanthavigar, K. Srinivasamoorthy, K. Vijayaragavan, R. Rajiv Ganthi S. Chidambaram, P. Anandhan, R. Manivannan , S. Vasudevan, (2010) Application of water quality index for groundwater quality assessment:Thirumanimuttar sub- basin, Tamilnadu, India, Environ Monit Assess , 171:595-609,

[3]. Mohammad Mehdi Heydari, Ali Abasi, Seyed Mohammad Rohani and Seyed Mohammad Ali Hosseini (2013), Correlation Study and Regression Analysis of Drinking Water Quality in Kashan City, Iran, Middle-East Journal of Scientific Research 13 (9): 1238 1244, ISSN 1990-9233.

[4]. S. Selvam, G. Manimaran, P. Sivasubramanian, ,( 2013), Hydrochemical characteristics and GIS-based assessment of groundwater quality in the coastal aquifers of Tuticorin corporation, Tamilnadu, IndiaAppl Water Sci, V-3:145-159 ,DOI 10.1007/s13201-0120068-8

[5]. V. Ramakrishna (2014) A Study on Ground Water Quality Comparison,Inr Jr of Engg Res \& Tech Vol. 3 Issue 2, pp-819-822, ISSN: 2278-0181

[6]. Ramakrishna V.(2011). Modeling For Water Quality Prediction Using Regression and Artificial Neural Networks, Acharya Nagarjuna University.

[7]. WHO. (2004). Guidelines for drinking water Quality. Geneva.

[8]. APHA, (1995), Standard Methods for Examination of Water and Waste Water,19 th edn., American Public Health Association, Washington, D.C

[9]. WHO. (1996). Guidelines for drinking water Quality. Geneva.

[10]. APHA, (1998) Standard Methods for the Examination of Water and Wastewater, 20th ed., American Public Health Association, Washington DC, pp: 2005-2605.

[11]. ]Ramakrishnaiah. CR, Sadashivaiah. C, Ranganna. G (2009) Assessment of Water Quality Index for the Groundwater in Tumkur Taluk, Karnataka State, India. E-Journal of Chemistry 6: 523-530.

[12]. World Health Organization (WHO),(1984).Guideline of drinking quality (pp. 333-335). Washington, DC: World Health Organization.

[13]. Sudhakar G and Swarna Latha G, (2013), Seasonal Variation of Ground-Water Analysis from Bapatla Mandal, Guntur District, Andhra Pradesh Int. Jrl of sci \& research, 2(11),231-233, ISSN No 2277- 8179.

[14]. Kumar .M and Kumar .R 2012, Determination of ground water quality, Int.Jr.Engg. Res \&Tech, 1(7), ISSN: $2278-0181$.

[15]. Tripathi B D, Dwivedi R K and Tripathi A, (1989), Water , air and soil pollution, 49, 107

[16]. Kalwale A M and Savale PA, 2012, Determination of Physico-chemical parameters of Deoli Bhoris Dam Water, Adv. Appl. Sci. Res.,3(1), 273-279.

[17]. Mehta, K.V., 2010. Physicochemical characteristics and statistical study of groundwater of some places of Vadgam taluka in Banaskantha district of Gujarat state (India), Journal of Chemical Pharmaceutical Research, 2(4): 663670 